\title{
ПРЕДПРИНИМАТЕЛЬСКАЯ ДЕЯТЕЛЬНОСТЬ В ПЕРИОД ПАНДЕМИИ КОРОНАВИРУСА: ПРОБЛЕМЫ, РИСКИ, ПЕРСПЕКТИВЫ
}

\author{
(c) 2020 Ревина С. Н. \\ профессор кафедры публичного права \\ Самарский государственный экономический университет, Россия, Самара \\ E-mail: 29.revina@mail.ru \\ (C) 2020 Смотрова И.В. \\ доцент кафедры гражданского и арбитражного процесса \\ Самарский государственный экономический университет, Россия, Самара \\ E-mail: i-smotrova@mail.ru
}

Обозначены ключевые причины кризисного состояния малого и среднего предпринимательства (МСП) в период пандемии коронавируса. Отмечены основные проблемы и проанализированы бизнес-риски для МСП, спровоцированные карантинными мерами, а также предложены возможные пути их предупреждения. Рассмотрены беспрецедентные меры государственной поддержки наиболее пострадавших от коронавируса отраслей малого и среднего бизнеса. Сделан акцент на том, что для сохранения предприятия и дальнейшего его развития необходима кардинальная перестройка форм и методов работы: переход в онлайн, роботизация процессов, удаленная работа, сокращение зарплаты и штата. Отмечены перспективы восстановления малого и среднего предпринимательства, обусловленные кризисом и закономерной цикличностью развития экономики.

Ключевые слова: экономика, малое и среднее предпринимательство, бизнес, коронавирус (COVID-19), пандемия, экономический кризис, безработица, меры государственной поддержки

Пандемия коронавируса (COVID-19) за несколько месяцев кардинально изменила мир, который, скорее всего, уже никогда не вернется к прежнему укладу. Распространение инфекции повлияло не только на образ жизни общества, трансформировало психологию и мировоззрение человека, профессиональную сферу, но и существенно сказалось на экономике, причем, не лучшим образом.

Практически во всех странах мира были предприняты экстренные противоэпидемические меры, которые привели к масштабному экономическому кризису, детонатором для которого послужило падение цен на нефть и снижение курса рубля. В особо сложной ситуации оказалось малое и среднее предпринимательство (МСП), роль которого в развитии экономики любого государства сложно переоценить. Последние исследования подтверждают закономерную зависимость экономического роста от относительного объема МСП и благосостояния населения. По данным Института экономики роста в большинстве развитых стран доля малых и средних предприятий в ВВП составляет 50-60\% [9]. Россия на сегодня значительно отстает в количественных показателях - 21,9\% [4] равно как и по показателям занятости в данном секторе. Тем не менее роль малых и средних предприятий в развитии национальной экономики приобретает все большую значимость. Благодаря им создаются рабочие места, внедряются инновационные технологические разработки, растет конкуренция. Конкуренция, в свою очередь, обеспечивает качество и рост товаров, влияет на производительность труда, стимулирует инновационную активность [13].

Сегодня в результате карантинных мер предпринимательская деятельность практически полностью остановилась. Миллионы предприятий малого и среднего бизнеса оказались на грани банкротства. В России угроза закрытия стоит перед каждой десятой компанией. Сомнительно, что сейчас кто-то может определенно ответить на вопрос о том, сколько из них смогут пережить рецессию и наладить бизнес после кризиса. Проведенный с в апреле компанией ЕY опрос показал, что 51\% предпринимателей малого и среднего бизнеса в текущей ситуации ограничительных мер смогут удержаться на плаву еще несколько месяцев. Причем, эксперты отмечают, что выживание бизнеса зависит не только от скорости восстановления денежного дохода, источ- 
ника инвестиций, локализации, персонала, но и от его размера. Около 20\% представителей МСП уже сейчас видят безысходность своего положения в то время, как многие крупные предприятия чувствуют себя более уверенно. Мониторинг мнения предпринимателей, занятых в малом и среднем бизнесе показал, что более $75 \%$ из них ожидают ухудшения экономической ситуации и обострения кризиса, вызванного карантинными мерами [11].

В поисках выхода из кризисной ситуации предприниматели пытаются спасти предприятия: перестраивают формат бизнеса и переходят на онлайн-продажи, автоматизируют процессы, сокращают объем производства, отправляют сотрудников в отпуск. Однако, в кратчайшие сроки реорганизовать и перепрофилировать деятельность компаний достаточно сложно и под силу не каждому руководителю.

Малое и среднее предпринимательство ведет свою деятельность практически во всех отраслях рыночной экономики, являясь ее важнейшей неотъемлемой частью, но при этом особенной уязвимой.

После проведенного анализа Правительство утвердило ряд отраслей экономики, наиболее пострадавших от введения карантинных мер, направленных на предупреждение распространения новой коронавирусной инфекции [1]. Однако, после обращения предпринимателей в Правительство с просьбой о признании их деятельности пострадавшей от COVID-19, список несколько раз уже обновлялся, пополняясь все новыми видами экономической деятельности. Вполне возможно, что перечень пострадавшего от инфекции бизнеса будет увеличиваться и дальше.

По оценкам экспертов, масштаб пострадавших от карантинных мер отраслей представляется по - разному. Так, представители МСП среди наиболее пострадавших от пандемии отраслей называют ресторанную отрасль (82,9\%), индустрию красоты и моды $(61,6 \%)$, сферу производства $(48,5 \%)$ [8].

В эту же категорию попали также отрасли развлечений, общественного питания, розничной торговли непродовольственными товарами.

Из-за распространения COVID-19 туристическая отрасль, которая среди всех отраслей занимает четвертое место по доле вклада в мировой ВВП, испытала влияние кризиса одной из первых. Государственные границы закрываются, люди находятся на самоизоляции, передвижение запрещено даже в пределах нескольких кварталов. В первую очередь из-за ограничительных мер пострадали азиатские страны, в которых значительную часть ВВП составляют доходы от туристического бизнеса (Таиланд, Макао, Филлипины, Мальдивы и др.). Существенный ущерб от потери дохода от туризма грозит Италии и Испании. Всемирный совет по путешествиям и туризму прогнозирует потерю в этой отрасли до 50 млн. рабочих мест.

Для российских туроператоров кризис, связанный с коронавирусной инфекцией, стал сильнейшим ударом за последние несколько десятилетий [5]. Туристические агентства несут расходы, оплачивая аренду и налоги, выплачивая зарплату сотрудникам, возвращая деньги за проданные туры.

В то же время на фоне всеобщего экономического кризиса 6\% предпринимателей отметили рост прибыли в период ограничений. Значительно приумножили свое состояние те, чей бизнес был связан с производством и продажей средств индивидуальной защиты, доставкой питания, товарами первой необходимости, онлайнуслугами.

Сложно сказать, сколько продлится самоизоляция. Однако, эксперты считают, что продление карантина еще на полгода грозит снижением ВВП до 20\%. Даже при самом благоприятном прогнозе скорого выхода из карантина, пострадавшие от коронавируса отрасли не скоро оправятся от экономических потрясений.

При условии отмены карантинных мер в середине июня, каждой пятой компании понадобиться не меньше года для восстановления. Для подавляющего большинства компаний МСП при том же условии - более двух лет.

Малый и средний бизнес в числе основных проблем, вызванных пандемией, называет убытки, падение потребительского спроса, сокращение персонала, срыв обязательств по выплатам налогов, повышение закупочных цен, сокращение заработной платы, недостаток оборотных средств. Эксперты считают, что на экономику в сложившейся ситуации влияет паническое состояние населения. Страх меняет сознание и поведение людей, меняет ценности и ориентиры. В итоге страх заболеть влияет на спрос и предложение в экономике [10].

Среди прочих проблем, вызванных карантинными мерами, президент Владимир Путин в 
выступлении на виртуальном экстренном саммите G20 назвал долгосрочную безработицу.

По подсчетам экспертов исследовательского холдинга «Ромир» и Gallup International, в результате экономического кризиса, спровоцированного распространением коронавируса, в России $12 \%$ населения уже оказались без работы [12]. Неутешительные данные дает также исследование Boston Consulting Group (BCG), которое прогнозирует увеличение числа безработных до 15\%. [3]. Порядка 9 млн. человек в России в 2020 году может остаться без работы из-за прекращения деятельности только малых и средних предприятий [6].

На фоне развернувшегося кризиса, вызванного новой инфекцией, в России разрабатывается множество нормативных актов как федерального, так и регионального значения, направленных на поддержку граждан и экономических сфер, наиболее пострадавших от пандемии коронавируса, перечень которых регулярно пополняется.

Для борьбы с распространением инфекции и ее последствиями Правительство сформировало фонд в размере 300 миллиардов рублей. В числе первоочередных мер поддержки пострадавших от пандемии МСП в России были введены налоговые каникулы (22 отрасли на конец апреля), отсрочка по налогам, безвозмездные субсидии, продление лицензий, мораторий на банкротство и проверку бизнеса, беспроцентные кредиты на зарплату, отсрочка арендных платежей [7]. Период действия большинства мер поддержки бизнеса предоставляется на полгода.

Однако, все не так просто. Для получения тех или иных льгот, разработаны условия и критерии их получения. Например, беспроцентный зарплатный кредит выдадут компании, деятельность которой составляет не менее 12 месяцев, и в отношении нее не введена процедура банкротства. На 1 апреля 2020 года количество работников в компании должно составлять не менее 90\% [2] от предыдущего месяца. В результате, поспешившие уволить работников предприятия, не смогли воспользоваться данной льготой. В течение полугода после окончания льготного периода кредиты на заработную плату и уплату страховых взносов планируется выдавать под сниженную ставку (4,00 процента годовых).

Абсолютно позитивно была воспринята безвозмездная выплата МРОТ сотрудникам из государственного бюджета. Эта помощь оказалась крайне необходимой и своевременной. Прежде всего, она позволит избежать увольнений, сохранить штат и разгрузить центры занятости. Подобная мера для российской экономики является беспрецедентной, поскольку не имеет аналогов в прошлом.

Однако, не все антикризисные меры, предложенные Правительством, вызвали положительные отклики. В частности, не вызвал восторга кредит на зарплату, поскольку предприниматели не видят в нем смысла из-за невозможности в дальнейшем его погасить, да и обязательный налог на зарплатный кредит не добавляет оптимизма. Вызвало споры и снижение страховых взносов для предприятий малого и среднего бизнеса в размере $15 \%$, которое действительно только для части заработка, превысившего размер МРОТ. На сегодня эта сумма составляет 12130 рублей [7].

По мнению представителей малого и среднего предпринимательства, предложенные меры доступны лишь части предприятий. Они не решают самой проблемы, а лишь оттягивают сроки. Так обстоит дело и с арендными платежами. Большинство предпринимателей арендуют помещение у частных лиц, которые не торопятся снижать арендную плату или давать отсрочку по оплате. К тому же у арендодателей также есть график и обязательства по погашению кредитов.

В принятии антикризисных решений наблюдается некоторое противоречие, которое отчасти нейтрализует позитивный эффект успешных действий. Последние направлены на решение ключевых задач, обусловленных распространением коронавирусной инфекцией и карантинными мерами: облегчение финансовой нагрузки, решение срочных неотложных финансовых и социальных проблем, перспективное налаживание стабильной работы после снятия ограничений, обеспечение деятельности и перезапуск как основных отраслей экономики, так и отраслей малого и среднего предпринимательства. Главное в этих мерах - не выделение денег, а их грамотное распределение и доведение до получателя.

По мнению экспертов, необходимо также увеличить масштаб и интенсивность оказываемой помощи, разработать стратегию выхода МСП из кризиса. Несмотря на неоднозначные прогнозы российских и зарубежных экспертов относительно состояния и дальнейшего развития экономики в условиях, затянувшихся на не- 
определенный срок противоэпидемических мер, специалистами ведется активный поиск путей дополнительных мер поддержки МСП и в дальнейшем его активного восстановления после кризиса.

Сложно сказать, что ожидает человечество в ближайшее время. Специалисты отмечают, что последствия коронавирусной инфекции приведут к неопределенности и значительным рискам в экономике. Несмотря на некоторое снижение зараженных коронавирусом и послабление ограничений, эксперты считают, что уже этой осенью велика вероятность новой вспышки заболевания COVID-19. Если это так, то предположения о продлении пандемии и сопутствующей рецессии до конца года станут реальностью. Действуя по сценарию, население уйдет на самоизоляцию, малый и средний бизнес, не успев развернуться, будет вынужден прекратить свою деятельность, что приведет к росту безработицы, снижению потребительского спроса и доходов, а также к снижению реального ВВП.

В случае ожидаемой активности МСП понадобится еще несколько лет для восстановления малого и среднего предпринимательства. Следует отметить, что любой кризис рано или поздно заканчивается. Кроме того, кризис - это не только бедствие для экономики государства, но и благо. Это условие и перспектива обновления и роста: роста производительности труда, увеличения эффективности производства, появления новых технологий, новых продуктов, изменения налоговой политики государства. Так, многие эксперты считают, что коронавирусная напасть станет драйвером развития цифровой экономики как одной из приоритетных задач в реализации национальных проектов России.

За несколько месяцев вынужденной самоизоляции выяснилась крайняя необходимость перевода некоторых процессов в онлайн. Практически все российские компании, в том числе сфера торговли и услуг, применяют в своей работе информационные технологии, а, учитывая сегодняшнюю ситуацию, интернет-торговля позволит избежать колоссальных экономических потерь и безработицы.

Для того, чтобы выжить, предприятиям малого и среднего бизнеса придется перестраиваться и осваивать информационные технологии в торговле, выстраивать новую выигрышную маркетинговую стратегию и перевести бизнес в бесконтактный режим. Это позволит предпринимателям резко сократить бизнес-передвижения, заключать договора через Интернет, а посредством облачных платформ (Zoom, Microsoft Teams, OpenTok) коммуницировать с работниками и клиентами. В свою очередь, цифровая грамотность становится обязательным требованием для современного работника, как одно из условий конкурентоспособности.

В перспективе выхода из кризиса меры поддержки МСП со стороны государства и региональных властей должны быть финансово более ощутимыми и масштабными, стратегически обоснованными и тщательно спланированными. В то же время, представители малого и среднего предпринимательства должны осознавать, что Российское Правительство не в состоянии финансово закрыть все проблемные зоны, потому очень важно представителям малого и среднего предпринимательства, используя меры государственной поддержки, ответственность за выход бизнеса из кризиса взять на себя, осваивая новые креативные формы работы с банками, онлайн-кредиторами с целью получения дополнительных кредитов [14] для выхода из кризиса и дальнейшего развития предприятия.

\section{Библиографический список}

1. Постановление Правительства РФ от 03.04.2020 N 434 (ред. от 26.05.2020) «Об утверждении перечня отраслей российской экономики, в наибольшей степени пострадавших в условиях ухудшения ситуации в результате распространения новой коронавирусной инфекции» // СПС «КонсультантПлюс».- Режим доступа: http://www.consultant.ru/document/cons_doc_LAW_349344/ (дата обращения: 27.05.2020)

2. Постановление Правительства РФ от 24 апреля 2020 г. N 576 «Об утверждении Правил предоставления в 2020 году из федерального бюджета субсидий субъектам малого и среднего предпринимательства, ведущим деятельность в отраслях российской экономики, в наибольшей степени пострадавших в условиях ухудшения ситуации в результате распространения новой коронавирусной инфекции» // СПС «Система ГАРАНТ».- Режим доступа: https://www.garant.ru/products/ipo/prime/doc/73855337/ (дата обращения: 27.04.2020). 
3. ВCG привела три сценария роста безработицы в России. [Электронный ресурс].- Режим доступа: https://ria. ru/20200529/1572149975.html (дата обращения 4.05.2020).

4. Доля малого и среднего предпринимательства в ВВП Российской Федерации // Федеральная служба государственной статистики: [сайт].- 2019. 7 нояб.- Режим доступа: https:/www.gks.ru/search?q=доля+малых+и+средних+предприятий+в+ВВП. (дата обращения: 5.06.2020).

5. Как пандемия коронавируса повлияла на туристический бизнес в России [Электронный ресурс].- Режим доступа: https://journal.tinkoff.ru/ask/russia-coronavirus/ (дата обращения: 24.04.2020).

6. Лещев. В. Миллионы россиян рискуют остаться без работы из-за коронавируса. [Электронный ресурс].- Режим доступа: https:/secretmag.ru/news/milliony-rossiyan-riskuyut-ostatsya-bez-raboty-iz-zakoronavirusa-21-03-2020.htm (дата обращения 27.04.2020).

7. Малый и средний бизнес: меры поддержки организаций и ИП из-за коронавируса. // СПС «Консультант Плюс. - Режим доступа: http://www.consultant.ru/cons/cgi/online.cgi?req=doc \&base=LAW \&n=352202\&fld=13 $4 \& d s t=1000000001,0 \& r n d=0.8306561695862504 \# 02698835930852941$ (дата обращения: 15.05.2020).

8. Малый и средний бизнес назвал самые пострадавшие отрасли [Электронный ресурс].- Режим доступа: https://www.rbc.ru/business/18/05/2020/5ec0e48b9a79476c0568bd13 (дата обращения: 27.04.2020).

9. Определена доля малого и среднего бизнеса в экономике // World trade center: [сайт]. - 2019. 11 марта.Режим доступа: https://wtcmoscow.ru/services/international-partnership/actual/opredelena-dolya-malogo-isrednego-biznesa-v-ekonomike/ (дата обращения: 3.04.2020).

10. Пол Донован. Экономика страха: как коронавирус изменит бизнес и потребителей. [Электронный ресурс].- Режим доступа: https://forbes-ru.turbopages.org/s/forbes.ru/biznes/395525-ekonomika-straha-kakkoronavirus-izmenit-biznes-i-potrebiteley (дата обращения 27.03. 2020)

11. Представители малого и среднего бизнеса ожидают ухудшения экономической ситуации в РФ [Электронный ресурс].- Режим доступа: https://finance.rambler.ru/other/44203088/?utm_content=finance_media\&utm_ medium=read_more\&utm_source=copylink (дата обращения: 27.04.2020)

12. Ромир/Гэллап интернешнл: изменение финансового положения землян в период пандемии по данным Romir и Gallup International. [Электронный ресурс].- Режим доступа: https://romir.ru/studies/romirgellapinterneshnl-izmenenie-finansovogo-polojeniya-zemlyan-v-period-pandemii-po-dannym-romir-i-gallupinternational (дата обращения: 12.04.2020).

13. Breitzman, Anthony and Hicks, Diana,» an Analysis of Small Business Patents by Industry and Firm Size « (2008). Стипендия факультета для колледжа науки и математики. 12. Available at: https://rdw.rowan.edu/csm facpub/12 (дата обращения: 30.04.2020)

14. Todd Baker \& Kathryn Judge, How to Help Small Businesses Sur vive COVID-19, COLUMBIA UNIVERSITY SCHOOL OF LAW, CENTER FOR LAW \& ECONOMIC STUDIES WORKING PAPER NO. 620 (2020). Available at: https:// scholarship.law.columbia.edu/faculty_scholarship/2639 (дата обращения 10.04.2020). 